\title{
THE LIFE AND CAREER OF WILLIAM LIVINGSTONE FORD (1913-1992), PIONEER IN THE DEVELOPMENT OF CANADIAN MARINE SCIENCE AND OCEANOGRAPHY
}

\author{
DONALD C. GORDON \\ 1 Prince Street, Suite 502 \\ Dartmouth, NS \\ B2Y $4 L 3$
}

\begin{abstract}
Dr. William Livingstone Ford played an important role in the development of Canadian marine science after World War II. Trained as a physical chemist, he spent the early part of his scientific career in the United States with Dupont and the Woods Hole Oceanographic Institution. From 1948 to 1965 he held various positions with the Canadian Defence Research Board across the country. The highlight of his long career was serving as the senior manager of the Bedford Institute of Oceanography in Dartmouth, NS from 1965 to 1978 . He was a prominent leader in the national marine science community and a member of the Nova Scotian Institute of Science. This article summarizes highlights of his distinguished career as a both a scientist and government manager and his many contributions to Canadian oceanography. He was a well-respected science manager who developed a productive and collegial management style that encouraged different agencies to work together on multidisciplinary programs.
\end{abstract}

\section{CHILDHOOD}

William (Bill) Livingstone Ford was born in Montreal, QC on 15 November 1913. His grandfather had been in the lumber business. His father was born in Scotland and was an accountant. When he was just six months old, the family moved to Vancouver, BC where his father went into the construction business and his sister Esther was born. Soon after, the family moved on to Victoria where his father operated a pile driving business and it was here that he spent most of his childhood. Being brought up on the coast, he developed a love of the ocean at an early age.

\footnotetext{
* Author to whom correspondence should be addressed: donald.gordon@ns.sympatico.ca or 902-469-2798
} 


\section{EDUCATION}

As a child, he attended schools in Victoria. At 15, he wanted to go to sea as a crewmember on a whaler. After graduating from Victoria College (now University of Victoria), he entered the University of British Columbia (UBC) where he earned a BSc in chemistry in 1936 followed by a MSc in physical chemistry in 1937. The topic of his master's research was the thermal decomposition of normal butyraldehyde. While at UBC, he became attracted to the ideas of the Oxford Group (later known as Moral Rearmament), which helped nurture later concerns about the military use of nuclear energy. He then moved on to Northwestern University in Evanston, IL where he pursued a doctoral degree in physical chemistry. During this period, his good friend Howard McMahon from Victoria College days introduced Bill to his sister Hazel. They became a couple and were subsequently married in Billings, MT in June 1939. They lived in Evanston until Bill finished his $\mathrm{PhD}$ in 1940. The subject of his doctoral research was the densities, heat capacities and heats of dilution of glycolamide.

\section{EARLY CAREER IN THE USA}

Bill began to his professional career in the United States. His first job was as a research chemist with Dupont de Nemours and Company in Wilmington, DE where he worked in their Nylon Research Center on the development of high strength nylon yarns for defence applications. This was just before the United States entered World War II in late 1941. Bill and Hazel lived in Arden, DE, an idyllic small town just outside Wilmington. During this period, Bill became aware of US efforts to develop the atomic bomb and was a member of a group of scientists (including Linus Pauling) who were concerned that atomic research was in the hands of the military.

He was not particularly happy in his job with Dupont and was more interested in pursuing a career in either wood chemistry or oceanography. He soon began exploring job possibilities back in the Pacific Northwest with the University of Washington, the US Fish and Wildlife Service, the University of British Columbia and the Fisheries Research Board of Canada (FRBC). The most promising opportunity was a potential oceanographer position with the National Research Council (NRC) based at the FRBC laboratory in Nanaimo, 
BC. Dr. John (Jack) Tully (1906-1987) of the FRBC and Dr. George Field (1905-2000) of NRC encouraged him to apply which he did. Bill had first met Jack Tully in 1937 when he visited Departure Bay by workboat while employed with his father's pile driving firm. They swam together off the FRBC wharf and Jack had planted the seed for Bill to consider a career in oceanography when he completed his graduate studies.

Unfortunately, because of his experience with Dupont, if he took this position he would be directed to do war work and put himself at the disposal of the Wartime Bureau of Technical Personnel. George Field was unable to convince the higher-ups in NRC that Nanaimo's need for Bill's skills should supersede the war effort and his application was subsequently refused by NRC to the surprise and disappointment of all three. In later correspondence, Jack Tully expressed his disappointment in this turn of events and told Bill that he would continue working hard to create a position for him with the FRBC at Nanaimo after the war when there would be better opportunities for peacetime oceanographic research. He also advised Bill to get some oceanographic experience and recommended the Woods Hole Oceanographic Institution (WHOI) on Cape Cod, MA.

Soon after, in August 1944, Bill contacted Columbus Iselin, Director of WHOI, about possible employment as a physical chemist. Initially he was told that the war work underway precluded hiring him since he was not an American citizen. However, shortly after, he had further correspondence with Dr. Alfred Redfield and learned that WHOI now saw need for physical chemistry in oceanography in their current wartime government contracts and future peacetime research. Subsequently, Bill went to Woods Hole for an interview and was immediately offered a job as a chemical and physical oceanographer. He eagerly accepted the position with the understanding that he would have to help out on war contracts as long as the war activity continued. By moving to Cape Cod, he and Hazel would be closer to her brother Howard McMahon who had also earned a PhD in physical chemistry and was now at the Massachusetts Institute of Technology in Cambridge, MA.

Bill and Hazel (now pregnant) moved to Woods Hole in September 1944. Up until this time, Bill's research had been laboratory-oriented with nothing to do with fieldwork and the oceans. He was ready and eager for a change. One of his first projects was developing a 
conductivity meter to be included in recording bathythermograph (BT) packages for submarines so that data on vertical temperature gradients could be included in ballasting procedures. While living in Woods Hole, their daughter Arden was born in December 1944, followed by Stephanie in February 1947.

In 1946, Bill participated with other WHOI scientists in Operation Crossroads, two nuclear weapon tests conducted by the United States military at Bikini Atoll in mid-1946. They were the first peacetime detonations of nuclear devices after the atomic bombing of Nagasaki and Hiroshima, Japan, in August, 1945. The purpose of the tests was to investigate the effect of nuclear weapons on ships. They were the first of many nuclear tests held in the Marshall Islands, and the first to be publicly announced beforehand and observed by an invited audience, including a large press corps. These tests are described in a 1988 American documentary film entitled 'Radio Bikini' which also explores the effects of nuclear explosions on the indigenous population and American servicemen involved in the testing.

The WHOI scientific team conducted numerous baseline studies in physical, chemical and biological oceanography and fisheries around Bikini Atoll prior to the bomb tests so that the effects, especially the radioactivity, could be properly assessed in post-blast surveys. The overall purpose was to predict the movement of radioactivity in the water. This operation was an early and large example of an environmental impact study. Bill was responsible for computing ocean currents in deep water around the atoll and setting up a laboratory for salinity measurements. He witnessed the detonations from a distance of 20 miles $(32.2 \mathrm{~km})$, an experience that had an enormous impact on him. As a result of this experience, he became very passionate against the use of nuclear weapons but seldom spoke of his concerns. When he did, there was fire in his eyes and a steel edge in his voice as he expressed his hope that they would never be used again. Building upon his interest in the Oxford Group during his UBC years, he became a very strong advocate of arms control and reduction. Bill felt that there should be a controlled explosion every five years which all world leaders had to attend for he believed that no one who had witnessed a nuclear explosion would ever launch a nuclear attack.

Also participating in Operations Crossroads was Dr. Gordon Riley (1911-1985) who later became the Director of the Institute of Oceanography at Dalhousie University in 1965. Other participants who also 
went on to distinguished careers in oceanography included Dr. Walter Munk (at the Scripps Institute of Oceanography) and Dr. William Von Arx (at the Woods Hole Oceanographic Institution) (Fig 1).

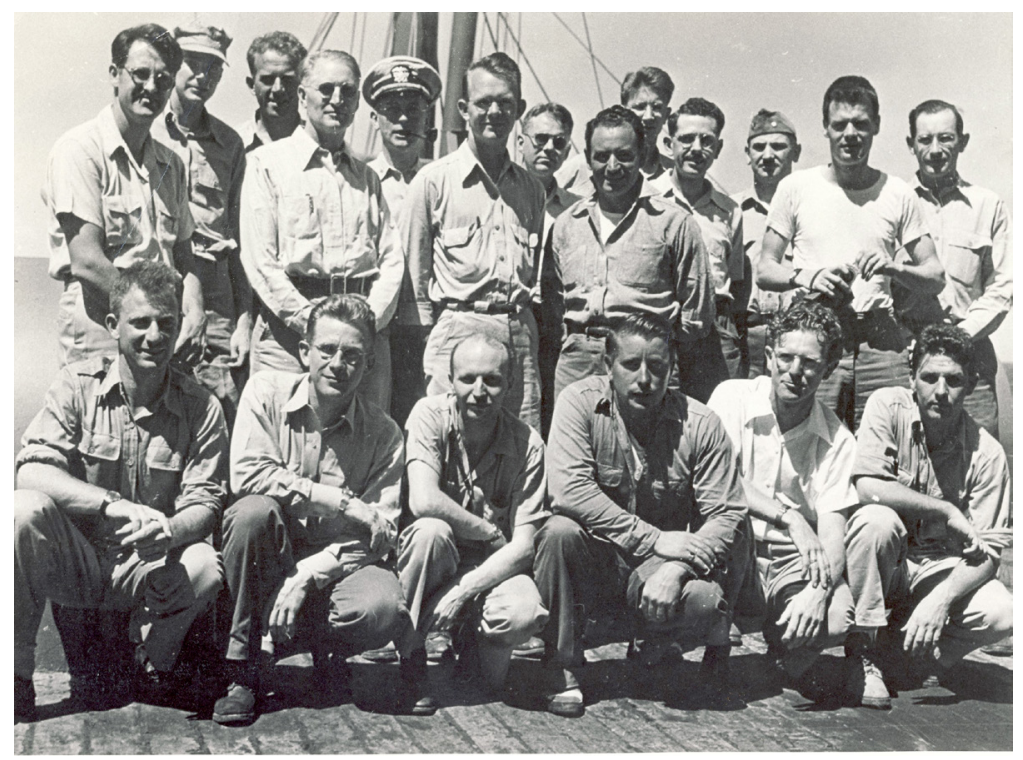

Fig 1 Scientific staff involved with Operation Crossroads on the USS Bowditch of the US Navy Hydrographic Office enroute to Bikini Atoll in 1946. Notable staff squatting in the first row include Bill Ford (second from right), Gordon Riley (fourth from right), Bill Von Arx (fifth from right) and Walter Munk (sixth from right).

\section{DEFENCE RESEARCH BOARD}

While much happier at WHOI than he was at Dupont, Bill still desired to eventually return to Canada and continued to explore job possibilities north of the border. He continued to correspond with Jack Tully who was still committed to create a position for Bill at the FRBC laboratory in Nanaimo, BC but nothing materialized. Bill was also in contact with Dr. Harry Hachey (1901-1985) of the newly established Atlantic Oceanographic Group (AOG) at the FRBC laboratory in St. Andrews, NB and was invited to apply for a position in physical oceanography. However, soon after this, Bill was offered a position with the newly established Naval Research Establishment of the Defence Research Board in Dartmouth, NS. He accepted this attractive position which he felt would be a good place to start a career back home in Canada 
and eagerly moved to Nova Scotia with his young family in 1948 . It was here that he re-established contact with Dr. John Aldous, another friend from Victoria College days, who was now the Chairman of Pharmacology at Dalhousie University. Soon after arrival, he was appointed Head of the Underwater Physics Section which was involved in acoustic research. This work involved frequent trips to St.Andrews, NB and interactions with Harry Hachey and other scientists in AOG.

In 1948, Bill participated with US colleagues in a survey of the Gulf Stream and adjacent surface waters. Later, in 1950, he led the participation of the Naval Research Establishment in Operation Cabot, a multi-ship survey of the Gulf Stream south of Halifax carried out in collaboration with WHOI and the US Navy Hydrographic Office. Bill served as chief scientist on HMCS New Liskeard, the Canadian ship in the fleet of six research vessels. They had the great thrill of making confirming observations on the neck of a great southward loop of the Gulf Stream that shortly after became a detached cold core eddy (Fuglister and Worthington 1951).

Bill also led a team which did pioneering work on variable depth sonar which led to an operational system deployed by the Canadian Navy and others. The techniques of high speed towing, noise suppression and cable design were later adapted to many non-military applications in oceanography and marine exploration geophysics. The latest sub-bottom reflection profilers can be regarded as direct descendants. The research program conducted at the Naval Research Establishment between 1940 and 1967 was reviewed by Longard (1993).

In 1952-53, he took a one-year international training course at the National Defence College in Kingston, ON which was a prestigious appointment for up and coming federal managers. He enjoyed his participation in the course, made invaluable contacts, and especially appreciated the opportunity to write a substantial essay on a topic outside his professional expertise. For this he chose to write about the history of the Russian Orthodox Church since the 9th century.

Following this course, Bill moved to Ottawa to become the Director of Scientific Services (Navy) for the Department of National Defence. This included coordinating naval-oriented research and development carried out by the Defence Research Board and coordinating the Royal Canadian Navy support to the Canadian oceanographic community.

In 1955, Bill moved back home to British Columbia to become Superintendent of the Pacific Naval Laboratory (PNL) of DRB in Esquimalt, the west coast equivalent to the Naval Research 




Fig 2 From left to right: Dr. Hartley Zimmerman (Chairman DRB), Dr. George Field (Vice Chairman DRB) and Bill Ford (Superintendent PNL) in 1956.

Establishment in Dartmouth (Fig 2). With a staff of 90, this laboratory undertook research in underwater and under-ice acoustics, fluid dynamics, magnetics, marine corrosion, and naval metallurgical problems. Details of this program are provided by Chapman (1998). During this period, he worked closely with Dr. William (Bill) English (born 1915), also at the PNL, and Jack Tully who was now head of the FRBC's Pacific Oceanographic Group in Nanaimo. Both became very good family friends.

In 1959, Bill returned to Ottawa and served as the Scientific Advisor to the Chief of Naval Staff. Then, in 1963, he became the Chief of Personnel for the Defence Research Board. During this period in Ottawa, he interacted with Dr. William van Steenburgh (1899-1974) of the Department of Mines and Technical Services and Dr. William Cameron (1914-2008) on loan from the University of British Columbia to the Defence Research Board when the concept of BIO was being nurtured. His advice was frequently sought during these formative years. He was considered as the first director of the Marine Science Branch laboratory at BIO when it opened in 1962 but the timing 
was not right for him so his close colleague Bill English of the PNL assumed this role.

\section{BEDFORD INSTITUTE OF OCEANOGRAPHY}

In 1965, Bill departed Ottawa and returned to Nova Scotia to become the second director of the Marine Sciences Branch (MSB) laboratory of the Department of Mines and Technical Surveys at BIO. Bill English, the first director, had previously returned to the PNL in Victoria, BC in 1964 and in the interim Dr. L.A. Earlston Doe (1916-2002) had served as acting director.

Bill considered his posting to BIO as his dream job (Fig 3). His four years at WHOI and 17 years at various government establishments across Canada had helped prepare him for his new responsibilities as a federal oceanographic research manager. He felt that BIO had the potential to become a world player in oceanographic research and, after many years in administrative positions, he was eager to get back into a research environment. He found it tremendously appealing to have the chance for some 'hands on' experience again. By the time he arrived, BIO had already grown to a staff of about 600 , including ship and support staff, and the extensive program included hydrography, physical oceanography, chemical oceanography, biological oceanography, marine geosciences and ocean engineering.

He was appointed with the title of Director, Bedford Institute of Oceanography when in fact he was responsible for only the program of the MSB. Other organizations at BIO at the time included the Canadian Hydrographic Service (CHS) and the Atlantic Oceanographic Group (AOG) of the FRBC and their directors reported separately to

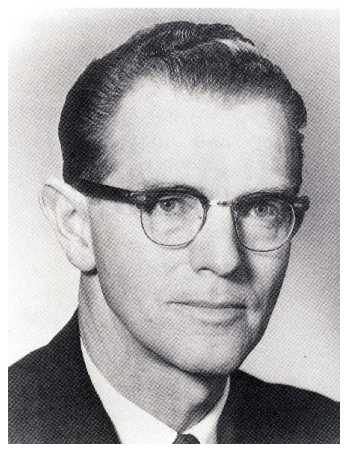

Fig 3 Bill Ford when he arrived at BIO in 1965. 
Ottawa through their own line management. However, the MSB was the lead agency which funded and managed the BIO infrastructure. Under these unique conditions (Gordon et al. 2014), it was not possible to have a director with overall program responsibility. Yet the underlying premise of $\mathrm{BIO}$ was the creation of a community of marine scientists that would work collaboratively and make efficient use of combined resources. Bill's challenge was to build a self-governing oceanographic community, a non-organization, superimposed upon the normal hierarchal structures of governmental units. The necessary governance of institute-wide matters of business was provided by a committee of directors that met frequently (Fig 4). The notion of multiple loyalties gained acceptance. Staff came to identify themselves as part of BIO with pride and yet without loss of identity to their parent agency. This unique structure, developed under Bill's leadership, proved to be a resilient, stabilizing factor in adjusting to the shock waves emanating from the frequent shuffling of departmental mandates and consequent organizational changes over the years.

Dr. Lloyd Dickie (born 1926) also arrived at BIO in 1965 to become director of AOG. In 1968, the Marine Sciences Branch was renamed the Atlantic Oceanographic Laboratory (AOL) while the AOG was renamed the Marine Ecology Laboratory (MEL). In 1972, Bill was appointed the first chairman of the Atlantic Regional Board

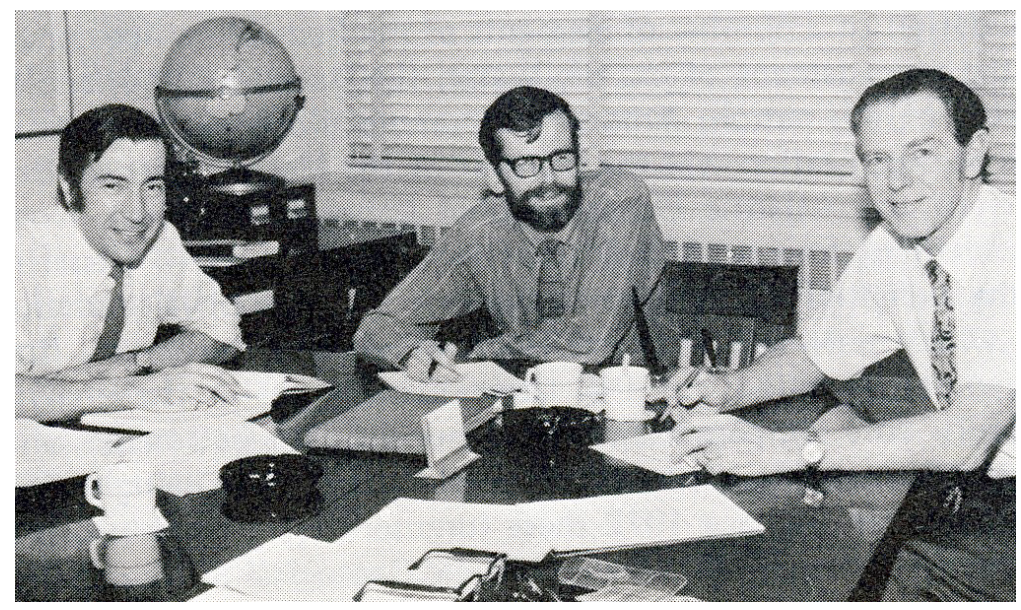

Fig 4 Bill Ford chairing a meeting of BIO Directors in 1972. Left to right are Bosko Loncarevic (Atlantic Geoscience Centre), Lloyd Dickie (Marine Ecology Laboratory) and Bill Ford (Atlantic Oceanographic Laboratory). 
of the newly created, federal Department of Environment. In 1976, he became Director-General of Ocean and Aquatic Sciences and was responsible for both the Atlantic Oceanographic Laboratory and the Marine Ecology Laboratory, as well as Institute Facilities.

Bill was at the helm of BIO during a period of unparalleled expansion. He led the development of BIO into a centre of marine research agencies and operational units, and strived to ensure that BIO programs were balanced among the various aquatic and marine science disciplines. He instilled a strong sense of collegiality and cooperation among the various agencies on campus, fostered multidisciplinary research, and was instrumental in building BIO into a major oceanographic institution of international standing. Throughout his time at $\mathrm{BIO}$, Bill was responsible for ensuring that the institute, comprised of several autonomous laboratories under two or more federal departments, functioned as a synergistic research community. He also nurtured close ties with universities, especially with the Institute of Oceanography across the harbor at Dalhousie University headed by Gordon Riley, his good friend from WHOI days.

Bill was a consummate administrator, a bureaucrat in the best sense of the word. He mastered the science of 'working the files' and never tackled a subject till he felt fully briefed. When Bill had an issue to deal with, he would review the available files and add his own comments. He would then circulate the files to staff involved, have a meeting and put a minute on file stating the decision reached. It was a cumbersome method which took time but the result was that everybody knew what was decided and how the decision was reached so that there were never hard feelings or suspicions that somebody had 'won' and others had 'lost'. This was exemplified particularly by the budget process. He was a remarkable and well-respected 'boss' and staff enjoyed working for him. He worked Ottawa hours because of the close contact needed with headquarters staff (primarily by phone in those days). He frequently returned to Ottawa for short periods to act for senior staff while they were away on vacation.

As well as being an accomplished and effective federal science manager, Bill made numerous scientific contributions during his tenure as BIO director. For example, he played an important role in the creation of the Hudson 70 Expedition that carried out the first circumnavigation of North and South America (Wadhams 2009) (Fig 5). He had planned to participate in this epic voyage but, in February1970, he was seconded to the Operation Oil Task Force as 


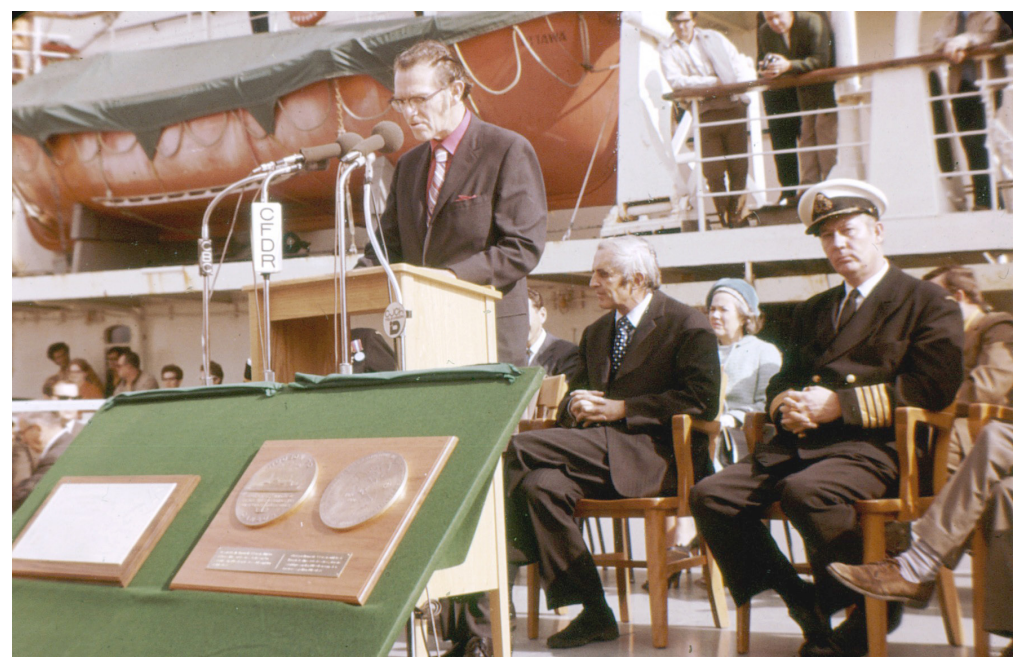

Fig 5 Bill Ford welcoming the CSS Hudson back to BIO after the Hudson 70 Expedition in 1970. The Honourable J. Greene and Captain David Butler are seated behind.

Scientific Coordinator to develop and lead a scientific team to tackle the scientific and technical problems associated with the Arrow oil spill in Chedabucto Bay, Nova Scotia (Operation Oil 1970). In 1971, he headed a delegation of Canadian scientists that visited Bermuda and advised its government on how to deal with the problem of pelagic tar washing up on their beaches. For six years (1972-1978), Bill was an official Canadian delegate to the International Council for the Exploration of the Sea (ICES). After retirement, he was a member of the Royal Commission that examined the causes of the Ocean Ranger disaster, the 1982 sinking of a semi-submersible drilling platform on the Grand Banks with the loss of all 84 crewmembers.

Other activities external to BIO included serving as the Canadian delegate on the NATO Committee on Oceanographic Research (19591963), the Atlantic Provinces Inter-University Committee on the Sciences (1966-1978), the NRC Committee on Geodesy and Geophysics (1967-1970), and the Defence Research Board Advisory Committee on Geophysical Research (1966-1973). In 1978 he was appointed to the Board of Directors of the Nova Scotia Research Foundation Corporation. He was a member of the Nova Scotian Institute of Science. He also was a director of the Canadian Associates of the Bermuda Biological Station. 
Bill endeavoured to develop a collegial atmosphere at BIO. Soon after he arrived in 1965, he and his wife Hazel instituted a series of intimate dinners at their home. The purpose was for Bill to get to know BIO scientists and to broaden personal contacts among BIO staff. These were most enjoyable and memorable events. Over the years, Bill hosted many meetings in his office at BIO. One of his traditions was buying coffee or tea for all the participants and his secretary, Joan Simms, made many trips to the CNIB cafeteria on his behalf. He also hosted many meetings while travelling, especially in his hotel room just before going out for dinner, where a bottle would always mysteriously appear. Bill also recognized the importance of bringing colleagues together socially to let off steam after participating in long and sometimes difficult meetings. He made it a point to visit the laboratories on a frequent basis to learn first hand about how work was progressing. He also maintained a custom of visiting BIO ships on Christmas Eve to thank the crews for their efforts in supporting the diverse research programs.

In 1969, Bill's wife Hazel was killed in a tragic car accident along with Eileen Aldous, the wife of John Aldous. A year later he married Marjorie Jones who was his faithful partner for the rest of his life.

Bill loved to go to sea and participated in BIO cruises whenever a bunk was available and he could arrange to get away. He enjoyed the challenges and rewarding nature of fieldwork, especially in the Arctic, and felt that spending time at sea participating in research programs with colleagues was an important part of his job. He was also a passionate and able recreational sailor who belonged to the Royal Nova Scotia Yacht Squadron. Bill owned a series of sailboats that he kept moored off his house in Boulderwood on the Northwest Arm. He loved to go cruising with friends and colleagues along the coast of Nova Scotia, especially down the Eastern Shore. Dr. Arthur Collin (b 1929), one of the AOG scientists when BIO opened in 1962 and later a senior science manager in Ottawa, was a frequent companion.

Bill retired in 1978 after serving 13 years as the senior manager of $\mathrm{BIO}$ and received many accolades from colleagues for his many accomplishments over a 38-year career as a research scientist and manager. Many of the highlights of his career were captured in an extensive interview published in the Halifax Chronicle-Herald (Deakin 1978). He was awarded honorary degrees from the University of New Brunswick and Dalhousie University. After his long friendship with Jack Tully, it was most fitting that in 1984, Bill won the Tully Award 
which is given annually to a person whose scientific contributions have had a significant impact on Canadian oceanography.

He and Marjorie were able to enjoy eight happy retirement years of travelling, sailing, and being with family and friends. Bill also did some scientific consulting. Unfortunately, in 1986 he suffered a major stroke that left him partially paralysed and unable to speak. Despite extensive therapy, he was never able to regain his mobility or speech and spent the rest of his life confined to a wheelchair. After such a physically and intellectually active life, it must have been very frustrating to him not to be able to participate fully. However, despite his disabilities, he maintained an active interest in the lives of his family and friends, as well as events at BIO, up to his death in 1992. His ashes were spread in the Labrador Sea from the Hudson.

Bill's most significant contribution over his long career was his profound and lasting impact on building BIO into the world-renowned oceanographic institution that it became by the 1970s and 1980s. In many ways his job was easier than that of those who followed him, because he was at the helm during the expansion years when federal government resources were readily available for new buildings, ships, staff and scientific projects. He did not have to seek outside funding and deal with the budget cuts that came later. However, he made the most of his opportunities and ensured that the program developed with a healthy balance among the different scientific disciplines but remained responsive to the important issues of the day. Above all, he instilled a spirit of goodwill and cooperation amongst the BIO agencies and staff that has continued to the present day. Bill was always an unselfish person who put the interests of others first and his greatest professional satisfaction came from watching BIO run smoothly and its staff make important scientific contributions, both basic and applied. It is no wonder that he was held in such high regard by all Institute staff. It was most fitting that the BIO auditorium was officially named the William L. Ford Auditorium on occasion of the $50^{\text {th }}$ anniversary of BIO in October 2012.

\section{SUMMARY}

Bill Ford played an important and influential role in the development of Canadian oceanography during the period of rapid expansion after World War II, the details of which are reviewed by Mills (2014). 
After returning to Canada following employment at Dupont and WHOI, he worked at both DRB and BIO. His most major accomplishment was leading the development of BIO into a world-class research organization. He was a well-respected government science manager who developed a productive and collegial management style that served Canadian science very well and encouraged different agencies to work together on multidisciplinary programs that addressed important national marine issues. He was passionate about the ocean and was a dedicated civil servant. He possessed a strong social consciousness, was well respected by all who knew him, and was a true gentleman and friend to many.

Acknowledgements First and foremost, I thank Bill for being an important mentor in my own career as a government scientist. I had the privilege of knowing him both as a family friend and respected colleague, and he taught me much by example. Bill's daughters, Arden Ford and Stephanie Ford Forrester, provided a wealth of information, including copies of his personal correspondence, which I endeavoured to incorporate. Bosko Loncarevic kindly provided some insightful memories of his close working relationship with Bill. I also thank David McKeown, Arthur Collin, and especially Eric Mills, for their comments on earlier drafts of this contribution.

\section{REFERENCES}

Chapman, R.P.(Ed.) (1998). Alpha and omega-An informal history of the Defence Research Establishment Pacific, 1948-1995. Defence Research Establishment Atlantic, Dartmouth, NS. 283 p.

Deakin,B. (1978). Staggering memory: Bikini's A-bombs. Halifax ChronicleHerald, November 18, 1978.

Fuglister, F.C. \& Worthington, L.V. (1951). Some results of a multiple ship survey of the Gulf Stream. Tellus 3:1-14.

Gordon, D.C, Sinclair, M.M., Lewis, C.F.M. \& Nettleship, D.N. (2014). The Bedford Institute of Oceanography: a unique experiment in federal science. Pages 13-20 in Voyage of Discovery: fifty years of marine research at Canada's Bedford Institute of Oceanography (D.N. Nettleship, D.C. Gordon, C.F.M. Lewis, and M.P. Latremouille, Eds.). Bedford Institute of Oceanography - Oceans Association, Dartmouth, NS. 444 p.

Longard, J.R. (1993). Knots, volts and decibels - An informal history of the Naval Research Establishment, 1940-1967. Defence Research Establishment Atlantic, Dartmouth, NS. 113 p. 
Mills, E.L. (2014). Canadian marine science from before Titanic to the establishment of the Bedford Institute of Oceanography in 1962. Pages 3-11 in Voyage of Discovery: fifty years of marine research at Canada's Bedford Institute of Oceanography (D.N. Nettleship, D.C. Gordon, C.F.M. Lewis, and M.P. Latremouille, Eds.). Bedford Institute of Oceanography - Oceans Association, Dartmouth, NS. 444 p.

Operation Oil. (1970). Report of the Task Force - Operation Oil to the Minister of Transport. Information Canada, Ottawa, ON.

Wadhams,P.(2009). Hudson-70: the first circumnavigation of the Americas. Oceanography 22: 226-235.

\section{APPENDIX}

\section{Scientific Publications of William Livingston Ford in chronological order:}

Gucker, F.T. Jr. \& Ford, W.L. (1938). The specific heat of "Lucite" (methyl methacrylate polymer). Journal of the American Chemical Society 60:2563-2563.

Gucker, F.T. Jr., Ford, W.L. \& Moser, C.E. (1939). The apparent and partial molal heat capacities and volumes of glycine and glycolamide. Journal of Physical Chemistry 43:153-168.

Gucker, F.T. Jr., Packard, H.B. \& Ford, W.L. (1940). Thermodynamic properties of glycine at $25^{\circ}$. Journal of the American Chemical Society 62:2698-2704.

Gucker, F.T. Jr. \& Ford, W.L. (1941). The apparent and partial molal heat capacities and volumes of glycine and glycolamide. II. Results for concentrated solutions of glycolamide. Journal of Physical Chemistry 45:309-313.

Ford, W.L. (1949). Radiological and salinity relationships in the water at Bikini Atoll. Transactions of the American Geophysical Union 30: 46-54.

Ford, W.L. (1949). The field use of a salinity-temperature-depth recorder. Journal of Marine Research 8:84-96.

Ford, W.L. (1950). Seagoing photoelectric colorimeter. Analytical Chemistry 22:1431-1435.

Ford, W.L. \& Miller, A.E. (1952). The surface layer of the Gulf Stream and adjacent waters. Journal of Marine Research 11:267-280.

Ford, W.L., Longard, J.R. \& Banks, R.E. (1952). On the nature, occurrence and origin of cold low salinity water along the edge of the Gulf Stream. Journal of Marine Research 11:281-293.

Ketchum, B.\& Ford, W.L. (1952). Rate of dispersion in the wake of a barge at sea. Transactions of the American Geophysical Union 33: 680-684.

Ford, W.L. \& Hattersley-Smith, G. (1965). On the oceanography of the Nansen Sound Fiord System. Journal of the Arctic Institute of North America 18:159-171.

Garner, D.M. \& Ford W.L. (1969). Mid-Atlantic Ridge near $45^{\circ}$ N. Water properties in the Median Valley. Canadian Journal of Earth Sciences $6: 1,359-1,363$. 
Loncarevic, B.D.,Ford W.L.\& McMullen,R.M.(1969). Atlantic Oceanographic Laboratory, Bedford Institute: the first six years. The Polar Record 14:807-813.

Operation Oil. (1970). Report of the Task Force - Operation Oil to the Minister of Transport. Information Canada, Ottawa, ON.

Ford, W.L.\& Mason C.S. (1971). Operation Oil. Bedford Institute Biennial Review 1969/70 (G. Elliott, Ed.). Dartmouth, NS.

Ford, W.L. (1973). The health of the environment and the quality of life. Bedford Institute Report 73-4, Dartmouth, NS.

Note: Bill Ford also wrote a number of research reports on high strength nylon spinning processes while working for Dupont, numerous classified reports on underwater acoustics and submarine warfare while working for $\mathrm{DRB}$, and numerous annual reports for government research laboratories. As well, he presented invited addresses at many major conferences.

\section{Honourary Degrees}

Doctorate of Science, University of New Brunswick (1978)

Doctorate of Laws (honoris causa), Dalhousie University (1979)

\section{Awards}

J.P. Tully Medal in Oceanography (1984)

\section{Memberships}

Arctic Institute of North America

American Society of Limnology and Oceanography

American Association for the Advancement of Science

Canadian Meteorological and Oceanographic Society

Nova Scotian Institute of Science

Bermuda Biological Station 